\title{
FAVORABILITY MAPPING OF HYDROTERMAL VEIN-TYPE LEAD DEPOSITS: A CASE STUDY IN RIBEIRA VALLEY, BRAZIL
}

\begin{abstract}
The region of the Ribeira Valley is known for its metallic sulphide deposits (lead, zinc, copper, silver and gold), being the major lead producer of the Brazil in the 1950s. Since then, it has become the target of several geological studies from which two models of lead and zinc mineralization known as Perau and Panelas models were proposed. This study is particularly interested in the Panelas model, which is characterized by its vein morphology, association with carbonate rocks and structural control. Based on literature, this paper proposes to verify the applicability of the hierarchical analysis process (AHP) as auxiliary of the geographic information system (GIS) in the favorability mapping of hydrothermal veins-type $\mathrm{Pb}$ deposits which fit in the Panelas model. The study area is the western region of the Ribeira Valley, located in the southern portion of the São Paulo State, Brazil. In order to perform this work, four parameters were used: geological structure, stratigraphy, lithology and geochemistry. The result obtained highlights areas corresponding to Mina de Furnas, Bairro da Serra and Água Clara Formations as highly favorable areas to lead mineralization according this model. In addition, it shows the negative association of these geological formations with potassium concentration.
\end{abstract}

Keywords: Hierarchical analysis process; Ribeira Valley; Lead favorability; Panelas model.

\section{RESUMO}

MAPEAMENTO DA FAVORABILIDADE DE DEPÓSITOS HIDROTERMAIS DE CHUMBO DO TIPO VEIO: UM ESTUDO DE CASO NO VALE DO RIBEIRA, BRASIL. A região do Vale do Ribeira é conhecida por seus depósitos de sulfetos metálicos (chumbo, zinco, cobre, prata e ouro), sendo o maior produtor de chumbo do Brasil na década de 1950. Desde então, essa região tornou-se alvo de vários estudos geológicos os quais propuseram dois modelos de mineralização de chumbo e zinco conhecidos como modelos Perau e Panelas. O presente estudo é particularmente focado no modelo Panelas, o qual é caracterizado pela sua morfologia filonar, sua associação com rochas carbonáticas e seu controle estrutural. Com base na literatura, este artigo propõe verificar a aplicabilidade do processo de análise hierárquica (AHP) como auxiliar do sistema de informações geográficas (SIG) no mapeamento de favorabilidade dos depósitos hidrotermais de chumbo do tipo veio que se encaixa no modelo Panelas. A área de estudo é representada pela região oeste do Vale do Ribeira, localizado na porção sul do estado de São Paulo, Brasil. Para realizar este trabalho, foram utilizados quatro parâmetros: estrutura geológica, estratigrafia, litologia e geoquímica. O resultado obtido destaca áreas que correspondem às formações Mina de Furnas, Bairro da Serra e Água Clara como áreas de maior favorabilidade à mineralização de chumbo de acordo com esse modelo. Além disso, o resultado mostra associação negativa dessas formações com concentração de potássio.

Palavras-chave: Método de análise hierárquica; Vale Ribeira; Favorabilidade de chumbo; Modelo Panelas. 


\section{INTRODUCTION}

The region of Ribeira Valley is known for its great mineral potential, especially the metal sulfide mineralization such as lead, silver, zinc and copper (ARAÚJO 1999, CHMYZ 2011, CALTABELLOTTA et al. 2017, LOPES et al. 2017, MORAIS 2017). LOPES et al. (2017) report that this region represented the largest Brazilian metallurgical center for lead and silver in the 1950s. According to SILVA \& TEIXEIRA (2012), the lead reserves in the Ribeira Valley are estimated at 16.6 tons and have an average content of $8.05 \%$. Geological studies of these metal deposits in different deactivated mines, dated from the 19th and 20th centuries, allow to establish two main mineralization models known as Panelas and Perau models (FLEISCHER 1976, SILVA et al. 1982, MACEDO 1987).

The mineralization of the Perau model is characterized by its stratiform morphology and its hosting in sedimentary and metasedimentary rocks of marine origin (FIGUEIREDO 1992, ARAÚJO 1999, ARAÚJO \& MACEDO 2004). Some authors (e.g., SILVA et al. 1982, MACEDO 1987, DAITX 1996) attribute these mineral deposits to the Sedex model. The latter corresponds to the sedimentary exhalative deposits formed by the release of metalliferous hydrothermal fluids in the ocean floor (ARAÚJO \& MACEDO 2004). These metal-laden fluids reach the surface of the oceanic crust by normal faults or zones of crustal weakness (ARAÚJO \& MACEDO 2004, PIRAJNO 2009) and are deposited in the form of lenses or layers of massive sulfide of $\mathrm{Pb}$ and $\mathrm{Zn}$ associated with $\mathrm{Au}, \mathrm{Ba}$ and $\mathrm{Cu}$ (WINGE et al. 2001). Usually, the Sedex $\mathrm{Zn}-\mathrm{Pb}-\mathrm{Ag}$ deposits are hosted by marine sedimentary rocks - such as carbonaceous shales, siltstones, and (or) carbonates - of intracratonic or epicratonic rift basins (EMSBO et al. 2016).

The mineralization of the Panelas model is characterized by vein morphology, exclusive association with carbonate rocks (limestone and dolomite) and association with linear structures such as shear zones, faults, fractures systems and fold axis (FIGUEIREDO 1992, ARAÚJO \& MACEDO 2004, LOPES et al. 2017). This mineralization of hydrothermal origin is considered as an epigenetic mineralization (ODAN et al. 1978, CHIODI FILHO et al. 1982). The deposits of the Panelas model resulted from the hydrothermal remobilization of the metals of the supracrustal and basement rocks and, subsequently, by the precipitation of sulphide in the form of veins in the carbonate rocks (FLEISCHER 1976, SILVA et al. 1982, BARBOUR et al. 1990), especially the dolomites of the Votuverava Formation (Açungui Group), according to a general direction NE-SW (FIGUEIREDO 2000).

Based on the literature, this paper aims to verify the applicability of the hierarchical analysis process (AHP) as auxiliary of the geographic information system (GIS) for the favorability mapping of hydrothermal veins-type $\mathrm{Pb}$ deposits fitted in the Panelas model, which is one of the main mineralization models for the mineral deposits of the Ribeira Valley Region. The study area is the western part of this region and covers the municipalities of Itapirapuã-Paulista, Barra do Chapéu, Ribeira, Itaóca, Apiaí and Iporanga. It takes up a total area of $2994.97 \mathrm{~km}^{2}$ of Ribeira Valley, which is located in the southern region of São Paulo, Brazil (Figure 1).

\section{GEOLOGICAL SETTING}

Ribeira Valley region is the result of a collision of three tectonic terranes (Apiaí, Curitiba and Luís Alves) that occurred during the tectonic events known as the Brazilian cycle in the Upper Proterozoic and the Cambrian (BASEI et al. 1992). These terranes form two large tectonic compartments known as Apiaí Belt and Coastal Domain - Lower and Upper-Middle Proterozoic - in the southern portion of the São Paulo State (CPRM 2006). These compartments are separated by the Lancinha-Cubatão NE-SW dextral shear zone (DEHLER et al. 2000, CPRM 2006).

The Apiaí Belt or Apiaí Terrane is composed by the following lithostratigraphic units:

- The Três Córregos Granitic Complex and the Açungui Group, which are characterized mainly by low-to-medium-grade metamorphic rocks, in addition to the presence of several intrusive granitic bodies;

- The Água Clara and Perau Formations and the Embu Complex, formed by metasedimentary rock associations metamorphosed in higher degree (MARINI et al. 1967, HASUI \& SADOWSKI 1976, HASUI et al. 1975, PIEKARZ 1981, CAMPANHA 1991, FALEIROS et al. 2012). Lithologically, the Água Clara Formation is characterized by the presence of limestone, calcphyllite (calco-filitos), calc-schist, etc. (MARINI et al. 1967). 
The Coastal Domain, constituted by the Curitiba and Luís Alves terranes, forms the southern and southeastern portions of Ribeira Valley and contains five lithostratigraphic units (the Capiru Formation, the Sêtuva, Gneiss Migmatitic and Serra Negra Complexes and the Cachoeira Sequence), dominated by metasedimentary rocks that are intruded by magmatic rocks and based on gneissic-migmatite rocks (SILVA et al. 1981, CAMPANHA 1991, CAMPANHA \& SADOWSKI 1999, FALEIROS et al. 2012, MORAIS et al. 2012). The Curitiba and Luís Alves terranes are separated by the Serra do Azeite shear zone (FALEIROS et al. 2012).

The geology of the study area (Figure 1) is dominated by lithostratigraphic units composed of Mesoproterozoic metasedimentary and volcanic rocks (FIGUEIREDO 2000). MORAIS et al. (2012) described these units as follows:

- the Mina de Furnas Formation, constituted of metacalcarenite with cross stratification, calcic metacalcilutite, carbonate metabrechia;

- the Betari Formation, with metric banks of metaconglomerate interspersed with layers of

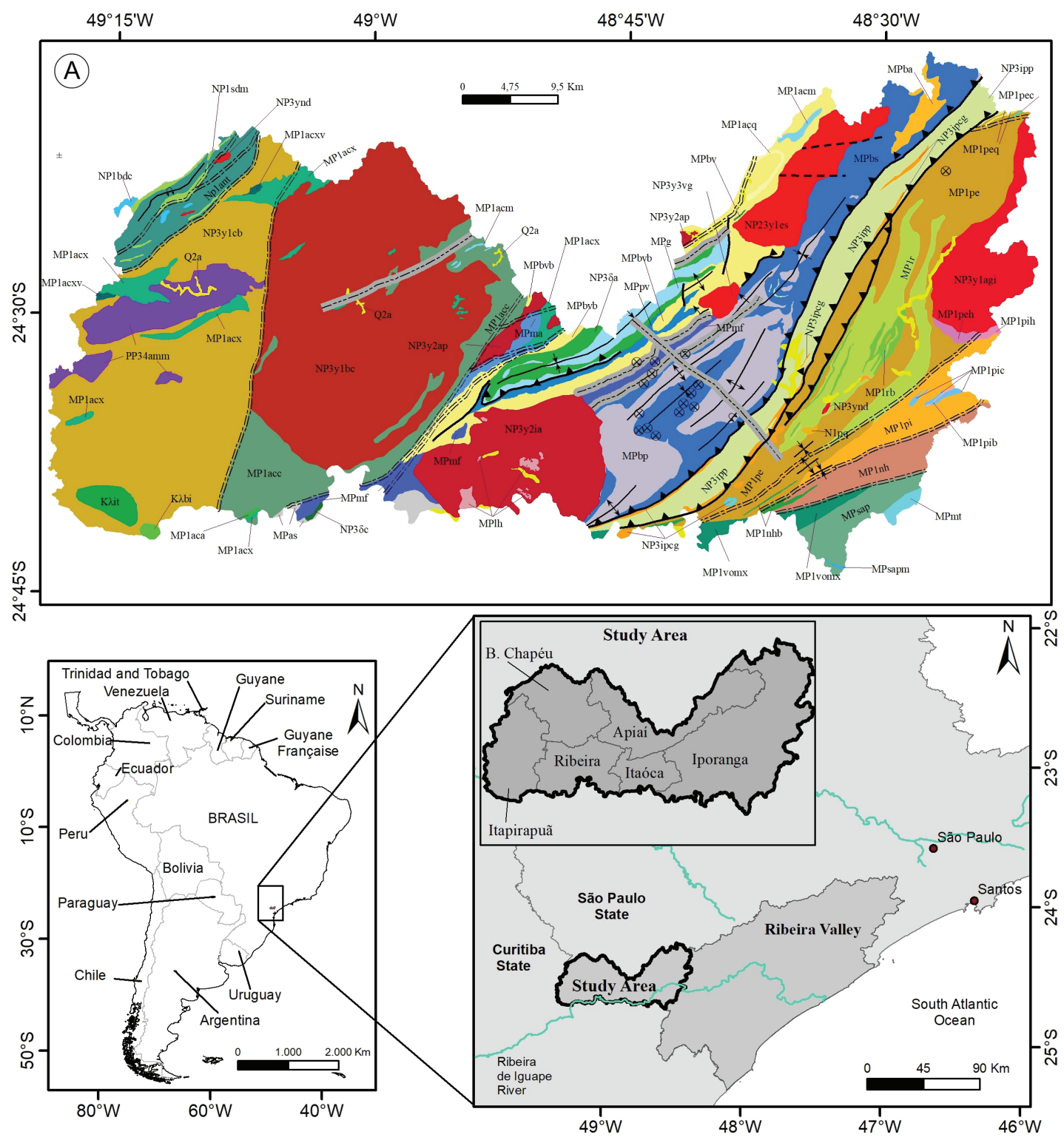

FIGURE 1 - (A) Geological map and location of the study area (modified from CALTABELLOTTA et al. 2017). 


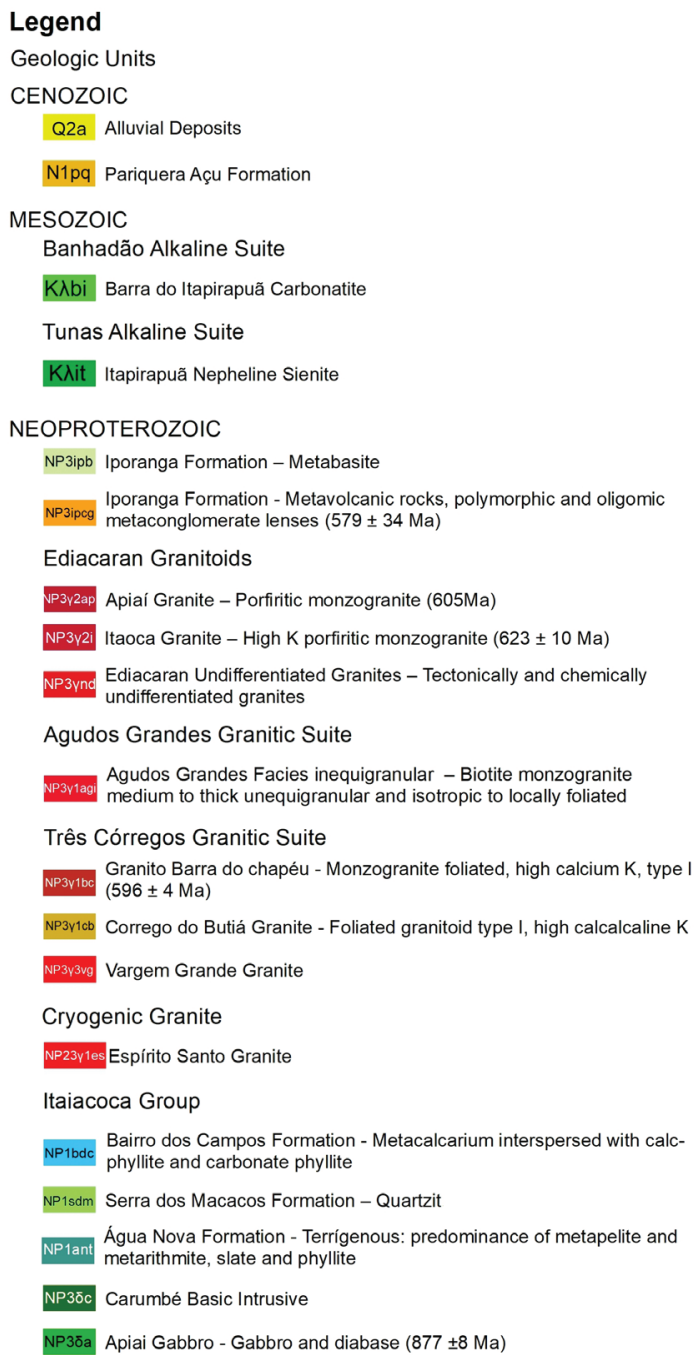

Gorotuba Formation -Metassiltite, phyllite, rhythmic turbidite, calciphyllite and marble

Passa Vinte Formation - Gray banded marble with algae mats,

MPpv metamarga, phyllite, and quartzite lenses

Serra da Boa Vista Formation - rhythmic meta-sandstone, quartzite, bv metasilite intercalations and metabasic rock lenses

Serra da Boa Vista Formation - rhythmic meta-sandstone, quartzite, MPbvb metasilite intercalations and metabasic rock lenses

Mpma Apiai Marble - Calcitic marble with deformed sedimentar structures

Mina de Furnas formation - metacalcarenite, calcitic metacalcilutite, carbonate metabrea, phyllite, sericite shale and quartz-sericite shale Água Suja Formation - Slate, phyllite and sericite shale with metaMPas conglomerate and quartzite lenses Bairro da Serra Formation - Metacalcare-

MPbsq $\begin{aligned} & \text { Bairro date, metacalcilutite and carbonate metabrea, with quartzite lenses } \\ & \text { nite }\end{aligned}$ Bairro da Serra Formation - Metacalcare-

MPbs nite, metacalcilutite and carbonate metabrea, with quartzite lenses

Betari Formation - pelitics: slate and phyllite, with rhythmic metassiltite/

Betari Formation - pelitics: slate and phyllite,
metargilite, turbidites and metabasite lenses

Betari Formation - Metapsamitic: Intercalation of layers of meta-

Mpba conglomerate with meta-sandstone and turbidite

MPIh Hornfels - Hornfels e escarnites

\section{Serra das Andorinhas Sequence}

MPmt Tapagem Marble - Dolomitic Marble, homogeneous to locally banded Metapelitic Unit - phyllite and micaxist, carbonatic with quartz bands and marble lenses

MPsap Metapelitic Unit - phyllite and micaxist, carbonatic with quartz bands

Votuverava Group

Ribeirão das Pedras Formation - Rhythmic phyllite with serecite and MP1pe metassiltite, intercalations of metachert and metarenite

Ribeirăo das Pedras Formation - Rhythmic phyllite with serecite and

metassiltite, intercalations of metachert and metarenite, and hornfels

Ribeirão das Pedras Formation - Rhythmic phyllite with serecite and

MP1peq metassiltite, intercalations of metachert and metarenite, and quartzit

MP1pec Ribeirão das Pedras Formation - Rhythmic phyllite with serecite and metassiltite, intercalations of metachert and calc-silicatic rock

Ribeirão das Pedras Formation - Rhythmic phyllite with serecite and

Ribeirão das Pedras Formation - Rhythmic phyllite with serecite
metassiltite, intercalations of metachert and metabasite lenses

Rubuquara Formation - Slate and phyllite with intercalations of meta-

MP1r $\begin{aligned} & \text { Rubuquara Formation } \\ & \text { sandstone lenses }\end{aligned}$

Rubuquara Formation - Slate and phyllite with intercalations of quartzite

MP1rq lenses

Rubuquara Formation - Slate and phyllite with intercalations of meta-

conglomerate lenses

Rubuquara Formation - Slate and phyllite with intercalations of metaba-

MP1rb site lenses

Piririca Formation -Metavulcanosedimentary phyllite carbonite with inter-

MP1pi calations of sericite quartz phyllite and metamarl

Piririca Formation - Metavulcanosedimentary carbonite with intercalations of sericite-quartz phyllite and hornfels

Piririca Formation -Metavulcanosedimentary phyllite carbonite with interMP1 pib calations of sericite quartz phyllite and quartz lenses

Piririca Formation - Metavulcanosedimentary phyllite carbonite with intercalations of sericite quartz phyllite and carbonatic phyllite

Nhunguara Formation - Chlorite-sericite phyllite with intercalations of

Pinh carbonaceous phyllite

Nhunguara Formation - Chlorite-sericite phyllite with intercalations of carbonaceous phyllite and metabasite lenses

Micaxist - micaxist with muscovite, chlorite, biotite and restricted occurrences of granade

Água Clara Formation

Carbonate lithofacies - Calc-silicatic rock with compositional banding and anfibolite shale

MP1acc Carbonate lithofacies - Calc-silicatic rock with compositional banding

Carbonate lithofacies - Calc-silicatic rock with compositional banding and MP1acm marble

Carbonate lithofacies - Calc-silicatic rock with compositional banding and quartzit

Carbonate lithofacies - Calc-silicatic rock with compositional banding,

micaxist and quartz-micaxist

Carbonate lithofacies - Calc-silicatic rock with compositional banding

and intercalations of volcanic shale layers

\section{PALEOPROTEROZOIC}

Apiaí-Mirim Complex

Migmatite and migmatite gneiss - (1752 Ma)

Structural

Fault Types

Shear Zone

— Strike -Slip Fault Left-Lateral Motion _Compressional Shear Zone

- - - - Strike -Slip Fault Right-Lateral Motion ===:= Dextral Transcurrent Shear zone

Fold Axes

Sinistral Transcurrent Shear zone

$\uparrow$ Normal Anticline

$\div$ Normal Syncline

U. Overturned Anticline

FIGURE 1 - (B) legend of the geological map (modified from CALTABELLOTTA et al. 2017). 
thick metarenite grading to decimetric levels of fine metarenite at the top of the unit;

- the carbonate and shale units of the Água Clara Formation, composed of banded calcosilicatic rocks with intercalations of pure marble and metabasite lenses and by micaxist quartz with graphite shale intercalations, respectively;

- the Votuverava Group, formed by homogeneous sericite phyllite with intercalations of carbonaceous phyllite, carbonate phyllite and metabasite lenses;

- the Passa Vinte Formation, consisting of a gray marble banded, locally with algal mats, metamarl, phyllite and calcoschist;

- the Apiaí Marble known as a calcitic marble, with deformed sedimentary structures.

Structurally, the area is crossed by a set of NE-SW shear zones, folding zones with NESW axes, and faults and fractures with different directions.

\section{PROSPECTIVE MODEL}

The data used in this study were obtained from the Companhia de Pesquisa de Recursos Minerais (CPRM) and they were collected as part of the project Áreas de Relevante Importância Mineral no Brazil (ARIM) - Vale do Ribeira. The factors considered for the favorability analysis are represented, in descending order of importance, by structure, stratigraphy, lithology and geochemistry.

The structural factor considers the shear zones as the most important structure, followed by faults and fractures (intermediate importance) and the fold axes (least important). The stratigraphic factor involves four stratigraphic units represented by the Mina de Furnas, Bairro da Serra, Água Clara and the Itaiacoca formations. According to LOPES et al. (2017), the NE-SW shear zones are the main structural features that contain the polymetallic veins of the $\mathrm{Pb}, \mathrm{Ag}, \mathrm{Zn}, \mathrm{Cu}$ e $\mathrm{Au}$. These authors also identify the Mina de Furnas, Bairro da Serra and Água Clara formations as the main stratigraphic units in which most polymetallic veins are concentrated. Therefore, in this study, these formations are considered as having the same importance, followed by the Itaiacoca Formation, which is mentioned by ARAÚJO \& MACEDO (2004) as a favorable area for this type of mineral deposit.

The lithological factor includes, in decreasing order of importance, the dolomite, the limestone and the metasedimentary rocks. This classification is justified by the fact that the veins-type mineral deposits of the Ribeira Valley are hosted mainly in the carbonate rocks. Nevertheless, the dolomitic rocks present even more storage conditions due to their greater competence in relation to the limestone. The higher competence favors opening of fractures under the action of tectonic stresses, in which the mineralized hydrothermal fluids percolate and deposit their metallic content (ARAÚJO \& MACEDO 2004).

The geochemical factor involves, from the highest to the lowest degree of importance, lead, zinc and copper anomalies. Lead anomalies constitutes the most important element, being the focus of this work. Zinc acquires more importance than copper, because its correlation with lead is slightly greater than the correlation of copper with lead.

The geochemical data used in this study, available for free download in the Geobank website (CPRM 2018), were obtained from the chemical analysis of stream sediments and rocks samples realized as part of the regional geochemical investigation performed by the CPRM. Here, copper and zinc are used as pathfinder elements, according to LEVINSON (1980), since the mineral deposits of this region are polymetallic of $\mathrm{Pb}, \mathrm{Ag}$, $\mathrm{Zn}, \mathrm{Cu}$ and $\mathrm{Au}$ (LOPES et al. 2017).

The definition of the degree of importance of each prospective factor is based on its logical relevance and its level of associative exclusivity with the veins-type mineral deposits (Panelas model). For example, the structural factor is classified as the most important due to the veinscharacteristic of the ore bodies. The second most important factor is the stratigraphy, since each mineralization model in the Ribeira Valley is associated with some particular lithostratigraphic unit (FIGUEIREDO 1992, 2000). The lithological factor is considered less important than the stratigraphic factor, because the Perau model is also associated with carbonate and metamorphic rocks (FIGUEIREDO 1992, 2000, ARAÚJO \& MACEDO 2004). The geochemical factor is less important than the mentioned above, because the geochemical anomalies do not indicate the presence of mineral deposits associated exclusively with the Panelas model. Furthermore, sometimes, the anomalous concentrations may be related to contamination due to human activities. 


\section{INTEGRATION AND PROCESSING OF THE GEOLOGICAL DATA}

The defined factors above and their elements or alternatives were submitted to a judgment process through the AHP, which is a multicriteria method used to support decision-making in problems with multiple criteria (MARINS et al. 2009), proposed by (SAATY 1977). This method consists of decomposing and dividing the problem to be treated, into factors, which are further decomposed, in turn, into new more detailed factors called alternatives. The figure 2 shows the structure of the model into two levels of judgment, represented by:

- the parity comparison of the alternatives of each factor;

- the parity comparison of the factors.

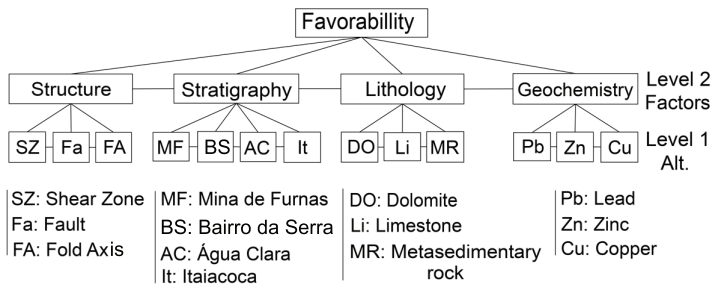

FIGURE 2 - Flowchart of the problem structured at the hierarchical level.
By using the conversion scale presented by SAATY (2002) (Table 1), the parity comparison done through a table known as judgment matrices (Tables 2 and 3) was performed.

TABLE 1 - Association of numerical and verbal classifications for parity comparison (SAATY 2002).

\begin{tabular}{cc}
\hline $\begin{array}{c}\text { Intensity of } \\
\text { Importance }\end{array}$ & Definition \\
\hline 1 & Equal importance \\
2 & Weak or slight \\
3 & Moderate importance \\
4 & Moderate plus \\
5 & Strong importance \\
6 & Strong plus \\
7 & Very strong or demonstrated importance \\
8 & Very, very strong \\
9 & Extreme importance \\
\hline
\end{tabular}

The judgment process of the pairs is followed by the normalization (Table 4), which is obtained by the sum of the lines of the judgment matrices and the later division of each line by the obtained sum. Finally, the arithmetic means of the new columns formed from this process result in a last column called Eigenvector.

After the definition of the weights by the AHP method, the geological data were submitted

TABLE 2 - Judgment matrices of the alternatives.

\begin{tabular}{|c|c|c|c|c|}
\hline Structural & Shear zone & \multicolumn{2}{|c|}{ Fault } & Fold axis \\
\hline Shear zone & 1 & \multicolumn{2}{|c|}{3} & 5 \\
\hline Fault & $1 / 3$ & \multicolumn{2}{|c|}{1} & 3 \\
\hline Fold axis & $1 / 5$ & \multicolumn{2}{|c|}{$1 / 3$} & 1 \\
\hline Sum & 1.53 & \multicolumn{2}{|c|}{4.33} & 9.00 \\
\hline Stratigraphy & Mina de Furnas & Bairro da Serra & Agua Clara & Itaiacoca \\
\hline Mina de Furnas & 1 & 1 & 1 & 3 \\
\hline Bairro da Serra & 1 & 1 & 1 & 3 \\
\hline Água Clara Form & 1 & 1 & 1 & 3 \\
\hline Itaiacoca Form & $1 / 3$ & $1 / 3$ & $1 / 3$ & 1 \\
\hline Sum & 3.33 & 3.33 & 3.33 & 10.00 \\
\hline Lithology & Dolomite & & Metc & imentary rocks \\
\hline Dolomite & 1 & & & 5 \\
\hline Limestone & $1 / 3$ & & & 3 \\
\hline Metasedimentary rocks & $1 / 5$ & & & 1 \\
\hline Sum & 1.53 & & & 9.00 \\
\hline Geochemistry & Lead & & & Copper \\
\hline Lead & 1 & & & 5 \\
\hline Zinc & $1 / 3$ & & & 3 \\
\hline Copper & $1 / 5$ & & & 1 \\
\hline Sum & 1.53 & & & 9.00 \\
\hline
\end{tabular}


TABLE 3 - Judgment matrix of the pairs of the factors.

\begin{tabular}{ccccc}
\hline Factors & Structure & Stratigraphy & Lithology & Geochemistry \\
\hline Structure & 1 & 3 & 5 & 7 \\
Stratigraphy & $1 / 3$ & 1 & 3 & 5 \\
Lithology & $1 / 5$ & $1 / 3$ & 1 & 3 \\
Geochemistry & $1 / 7$ & $1 / 5$ & $1 / 3$ & 1 \\
Sum & 1.78 & 4.53 & 9.33 & 16 \\
\hline
\end{tabular}

TABLE 4 - Normalized matrix of the factors.

\begin{tabular}{cccccc}
\hline Factors & Structural & Stratigraphy & Lithology & Geochemistry & Eigenvector \\
\hline Structure & 0.598802 & 0.662252 & 0.535906 & 0.4375 & 0.56 \\
Stratigraphy & 0.197605 & 0.220751 & 0.321543 & 0.3125 & 0.26 \\
Lithology & 0.11976 & 0.072848 & 0.107181 & 0.1875 & 0.12 \\
Geochemistry & 0.083832 & 0.04415 & 0.03537 & 0.0625 & 0.06 \\
\hline
\end{tabular}

to processing in GIS, in which thematic maps and a final map of favorability were generated. The different thematic maps are represented by the structural, stratigraphic, lithological and geochemical maps.

\subsection{Structure}

The structural map is based on the geological map from CPRM (CALTABELLOTTA et al. 2017). The main geological features used are represented by shear zones, faults and folded axes. A map of each feature (Figure 3 ) was generated separately and subsequently buffered with five concentric rings of $100 \mathrm{~m}$ each to define the areas of influence - the further the area is from the center, the less probable it is to find a deposit. The areas of influence of 500 $\mathrm{m}$ on both sides of the geological structures are defined, because, according to LOPES et al. (2107), NW-SE polymetallic veins $(\mathrm{Pb}, \mathrm{Ag}, \mathrm{Zn}, \mathrm{Cu}$ and $\mathrm{Au}$ ) cross the NE-SW shear zones. The resulting buffers of the features were processed through the Euclidean distance, which transformed them into new files capable to be summed (Figure 3). Using the weights calculated through the AHP, these maps were summed to generate a final structural map. This operation was performed using an algebraic equation, given by the equation 1 :

$$
\mathrm{S}=\alpha \mathrm{x}+\beta \mathrm{y}+\lambda \mathrm{z}, \quad(\text { Eq. 1) }
$$

In which:

$\mathrm{S}=$ Structure;

$\alpha=$ Shear zone;

$\beta=$ Fault;

$\lambda=$ Fold axis;

$\mathrm{x}, \mathrm{y}$ and $\mathrm{z}=$ the respective weights.

\subsection{Stratigraphy and lithology}

The stratigraphy and lithology maps were constructed based on the mineral resources map of ARIM, Ribeira Valley (SP and PR) (CALTABELLOTTA et al. 2017). From these maps, vector data were created, converted to raster data and, subsequently, reclassified with the weights calculated through the AHP method.

\subsection{Geochemistry}

An anomaly map of each of the chemical elements $(\mathrm{Pb}, \mathrm{Zn}$ and $\mathrm{Cu})$ of the geochemical factor was drawn by interpolation using the kriging and inverse distance weighted (IDW) methods and variograms.

\subsubsection{Geostatistics}

The analysis of the geochemical data distribution was performed using statistical tools such as histograms, normal Q-Q plot graphs and variograms. These tools allow the characterization and quantification of the relationships between different data.

The normal distribution produces a peak around the mean value and a low standard deviation. The normal Q-Q plot for the normal distribution is represented by a straight shape. In some cases, the data do not follow a normal distribution, so it is necessary a data transformation, which can be exponential, logarithmic, among others.

For the present study, the logarithmic transformation was used in order to construct normal Q-Q plot graph and histograms with lognormal distribution, because the evidence found 

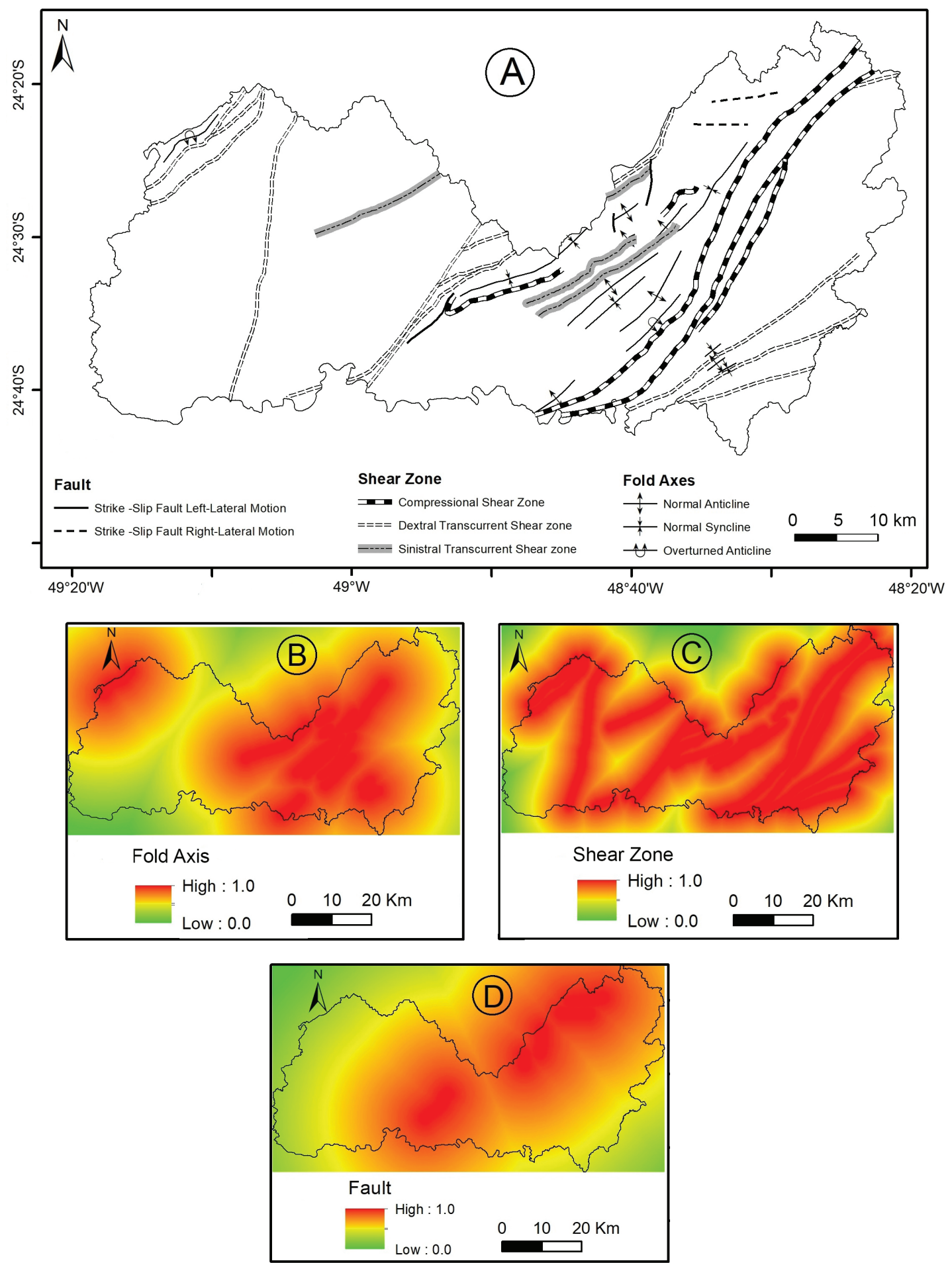

FIGURE 3 - (A) Structural map (features extracted from CALTABELLOTTA et al. 2017); (B) fold axis map; (C) shear zones map; (D) fault map.

in the literature shows that geochemical data have a normal or lognormal distribution (SHAW 1961 apud FRIZZO \& LICHT 2007). The lognormal distribution is characterized by the property of the data to follow a normal distribution, and it is used when the goal is modeling data with positive asymmetry (KOCH \& LINK 1970, ROSSI \& DEUTSCH 2014).

The copper data show lognormal distribution with mean and standard deviation equal to 17.887 
and 18.71 (Figure 4A). These values show that they do not follow a normal distribution. Another way to determine the non-normality is the shape of the histogram and the curve of the normal Q-Q plot graphic. In figure $4 \mathrm{~A}$, the data is almost totally concentrated in small values, so that the graphic is left skewed. In figure 4B, the logarithmic transformation in the histogram shows a symmetric distribution. In figure $4 \mathrm{C}$, the normal Q-Q plot before the lognormal transformation is represented with mean and standard deviations equal to 17.856 and 18.160 . This graphic shows a curve that is representative of non-normal distributions. After the transformation, the normal Q-Q plot shows a straight shape with $\mathrm{r}^{2}$ value equal to 0.99764 (Figure 4D). It is possible to see that the transformation effectively resulted in a lognormal distribution.

The lead data show lognormal distribution with mean and standard deviation equal to 64.79 and 378.99 (Figure 5A). These values do not follow a normal distribution. The histogram, after logarithmic transformation (Figure 5B), represents a symmetric distribution. The normal
Q-Q plot (Figure 5C) shows mean and standard deviation equal to 108.824 and 619.13. These values show a non-normal distribution. After the logarithmic transformation, the result is represented by the normal Q-Q plot (Figure 5D), that shows a straight shape with $\mathrm{r}^{2}$ value equal to 0.99368 , resulting in a lognormal distribution.

The zinc data show lognormal distribution with mean and standard deviation equal to 89.016 and 203.86 (Figure 6A). These values show that they do not follow a normal distribution. After the logarithmic transformation, the histogram represents a symmetric distribution (Figure 6B). For the normal Q-Q plot (Figure 6C), before logarithmic transformation the values of mean and standard deviation are equal to 108.824 and 619.13, respectively. After the transformation, the normal Q-Q plot shows mean and standard deviation equal to 108.824 and 619.13, respectively, and a straight shape with $\mathrm{r}^{2}$ value equals to 0.99337 , resulting in a lognormal distribution (Figure 6D).
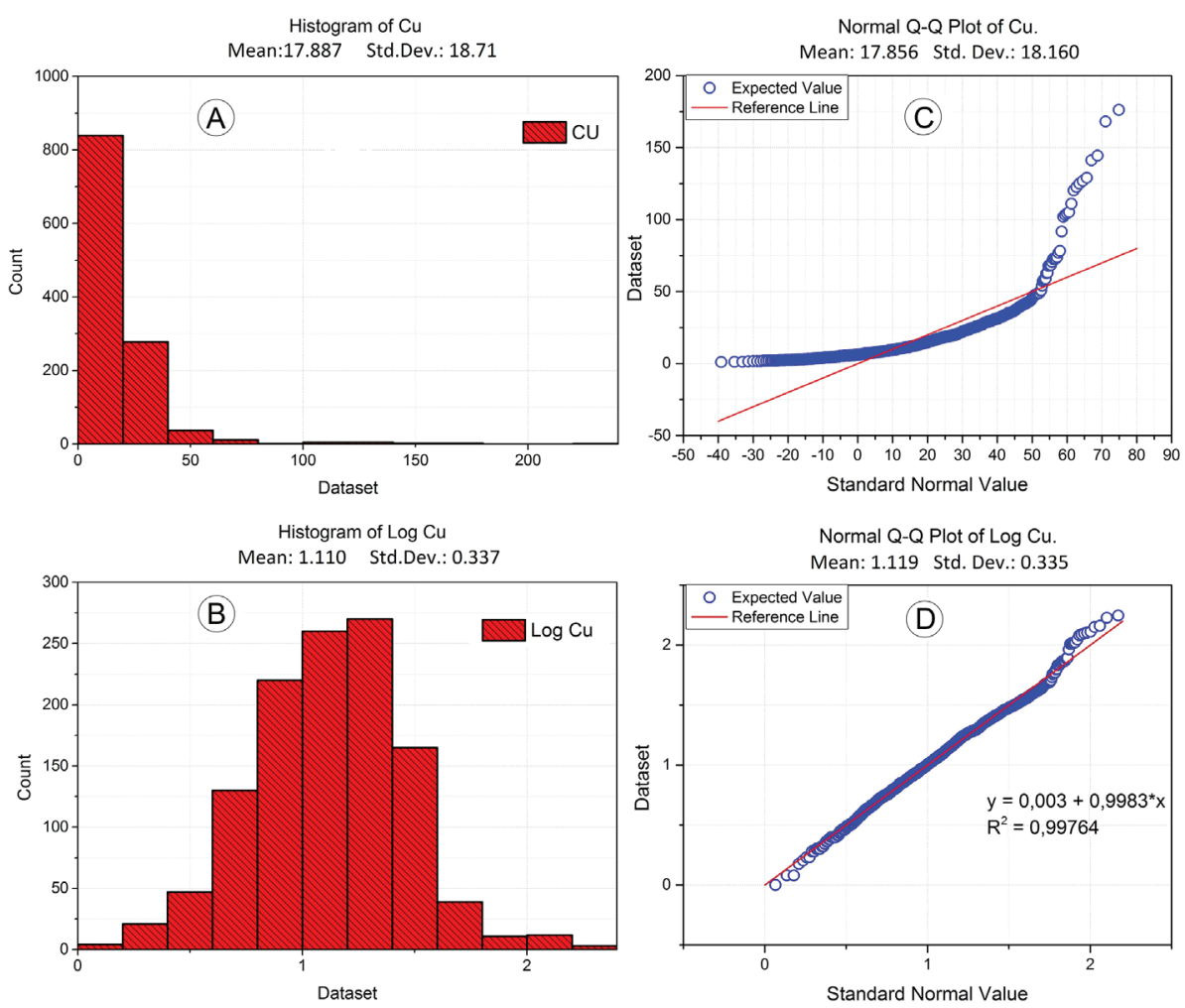

FIGURE 4 - (A) Histogram of $\mathrm{Cu}$ before logarithmic transformation; (B) histogram of $\mathrm{Cu}$ after logarithmic transformation; (C) normal Q-Q plot of Cu before logarithmic transformation; (D) normal Q-Q plot of Cu after logarithmic transformation (geochemical data extracted from CPRM 2018). 

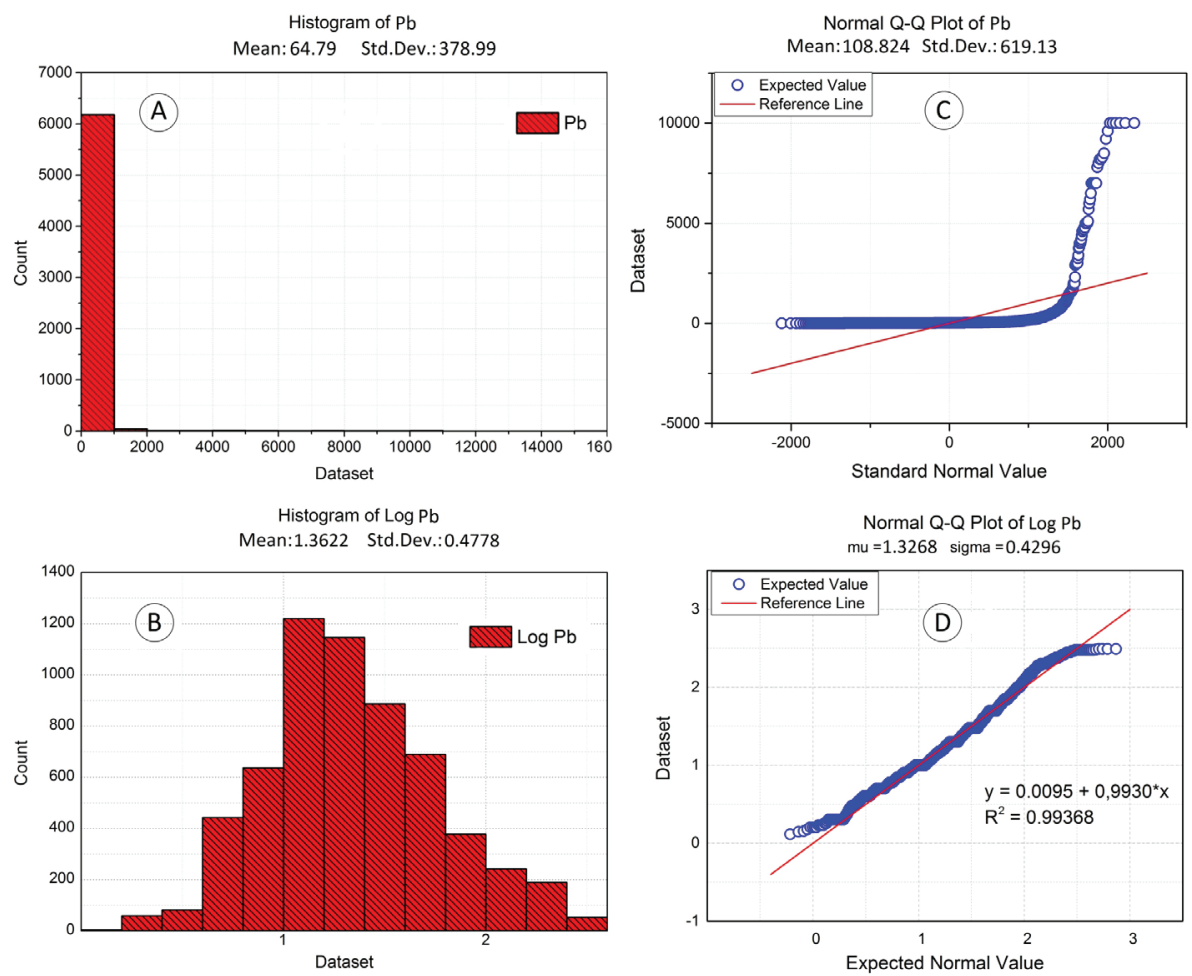

FIGURE 5 - (A) Histogram of $\mathrm{Pb}$ before logarithmic transformation; (B) histogram of $\mathrm{Pb}$ after logarithmic transformation; (C) normal Q-Q plot of $\mathrm{Pb}$ before logarithmic transformation; (D) normal Q-Q plot of $\mathrm{Pb}$ after logarithmic transformation (geochemical data extracted from CPRM 2018).
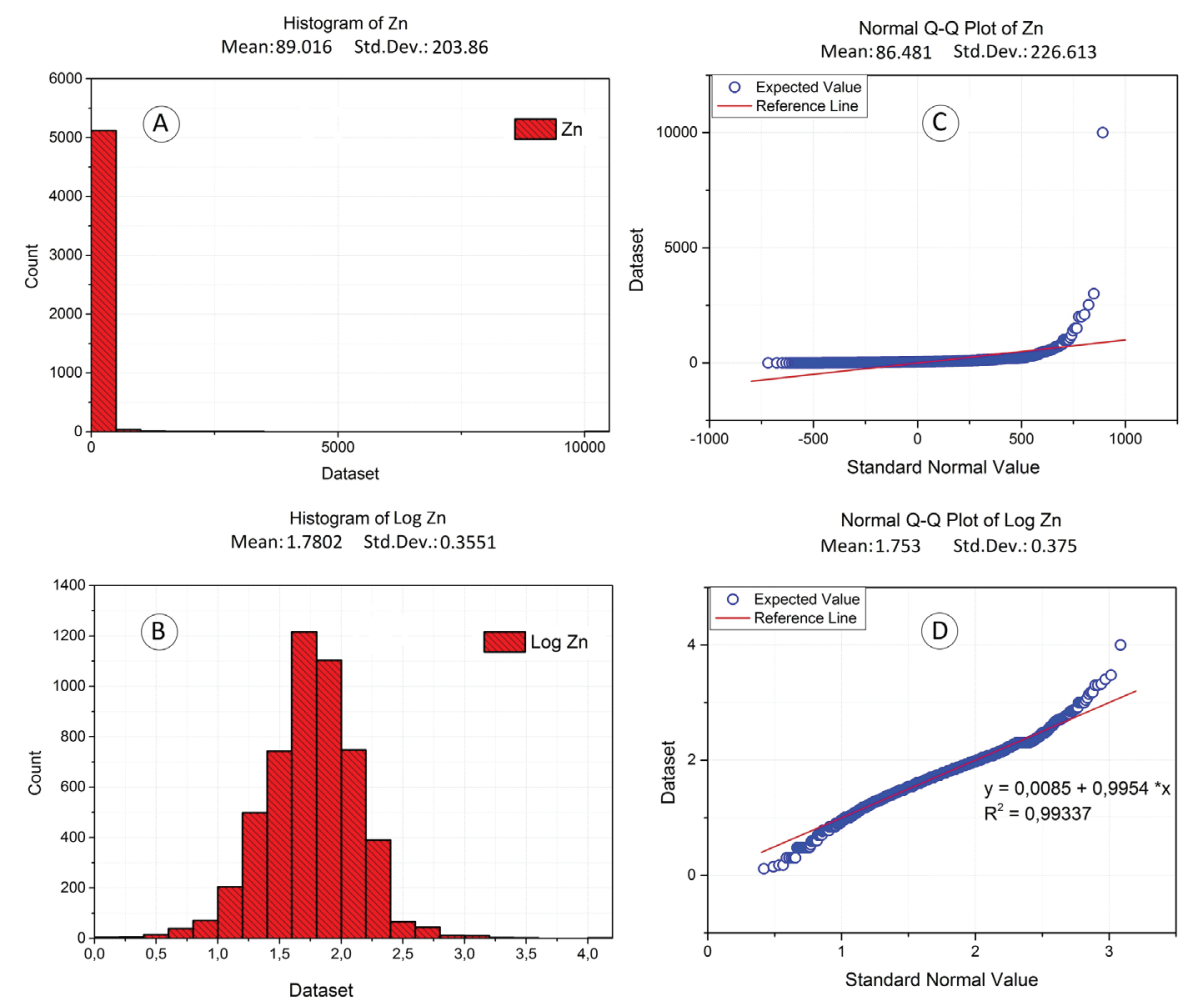

FIGURE 6 - (A) Histogram of $\mathrm{Zn}$ before logarithmic transformation; (B) histogram of $\mathrm{Zn}$ after logarithmic transformation; (C) normal Q-Q plot of Zn before logarithmic transformation; (D) normal Q-Q plot of Zn after logarithmic transformation (geochemical data extracted from CPRM 2018). 
The figure 7 illustrates the spatial distribution of stream sediment collection points for each element.

The copper map was constructed using the kriging interpolation method. The collect points are not well distributed and do not cover all the study area (Figure 7A). Thereby, it was necessary a robust tool of interpolation to reach all the extension of the area and to estimate correctly the values of the locals with no collection points. The kriging method ponders the nearest neighbors of the input point (YAMAMOTO \& LANDIM 2013). To calculate the parameters required for the construction of this map, it is essential to model the autocorrelation as a function of distance. The autocorrelation modeling is made by the semivariogram tool. This tool is used to describe the mathematical relationship between the variance of points and the distance separating this points. The nugget effect is the
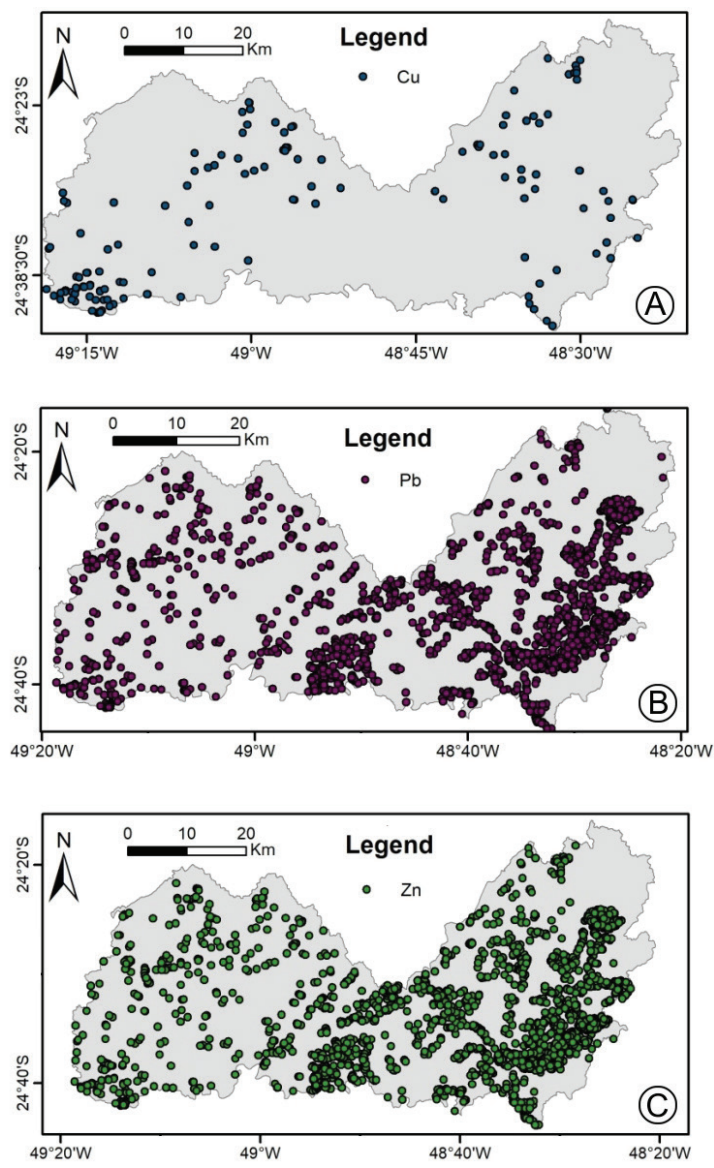

FIGURE 7 - Spatial distribution of collection points of stream sediments for each element: (A) copper, (B) lead, (C) zinc (Data extracted from CPRM 2018). initial point in the ordinate axis when $h=0$. The sill is the maximum value of the curve above which this point it is not more correlated, and the range is the maximum distance in which exists correlation. The lag distance is the distance, used in the construction of the semivariogram, between the input point and the neighbor.

The semivariogram of the $\mathrm{Cu}$ (Figure 8) were created with a lag distance of $0.00078 \mathrm{~km}$ or 12 neighbors. The semivariogram returned the values of nugget effect, sill and major range equal to $0.012,0.067$ and 0.0047 , respectively. This values were used in the construction of the geochemical map of copper.

The lead and zinc maps were constructed using the IDW interpolation method. The collection points in the maps (Figures 7B and 7C) are better distributed comparing with the $\mathrm{Cu}$, but restricted to the main streams. Therefore, it was not possible to follow a regular distribution.

The IDW interpolation assumes that each input point has an influence, in unknown points, that decreases with the distance. In this method, it is assumed that the rate of correlation between the each input points, and its neighbors are proportional to the inverse of the distance between them. Another parameter that is considered in this interpolation is the power parameter $\rho$ (BURROUGH \& MCDONNELL 1998). This parameter increases (or decreases) the influence of the neighbors in the estimates. In this maps, it was not necessary the construction of the variograms, because in IDW the weighting of the distance is made by the parameter $\rho$. The interpolation map was built by $\rho=2$ and maximum of 15 neighbors.

The maps of each element (Figure 9) were summed to generate a final geochemical map, using the weights calculated through AHP. In order to perform the operation, an algebraic equation was used, which is given by equation 2:

$$
\mathrm{G}=\alpha \mathrm{x}+\beta \mathrm{y}+\lambda \mathrm{z}
$$

In which:

$\mathrm{G}=$ geochemistry;

$\alpha=$ lead;

$\beta=$ zinc;

$\lambda=$ copper;

$\mathrm{x}, \mathrm{y}$ and $\mathrm{z}=$ the respective weights. 


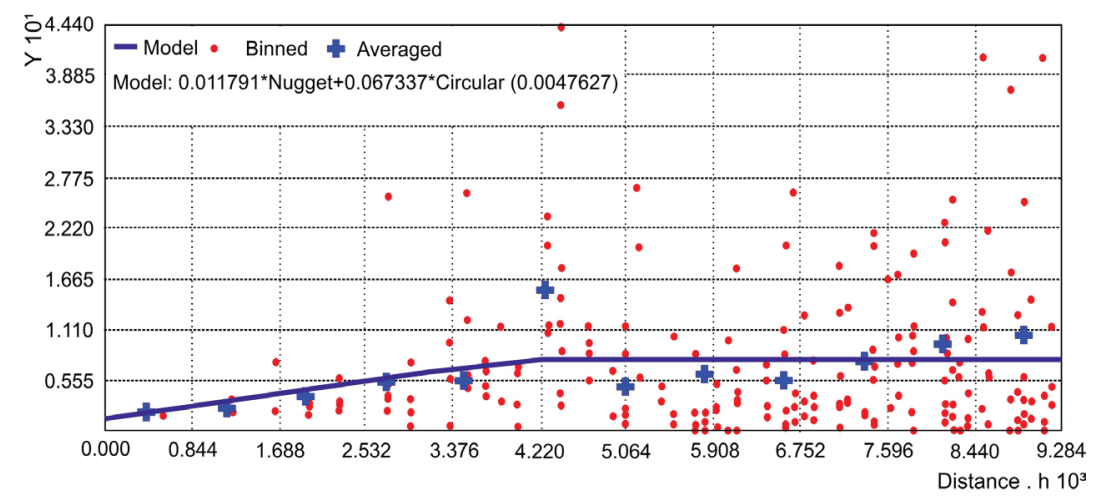

FIGURE 8 - Semivariogram for Cu (geochemical data extracted from CPRM 2018).
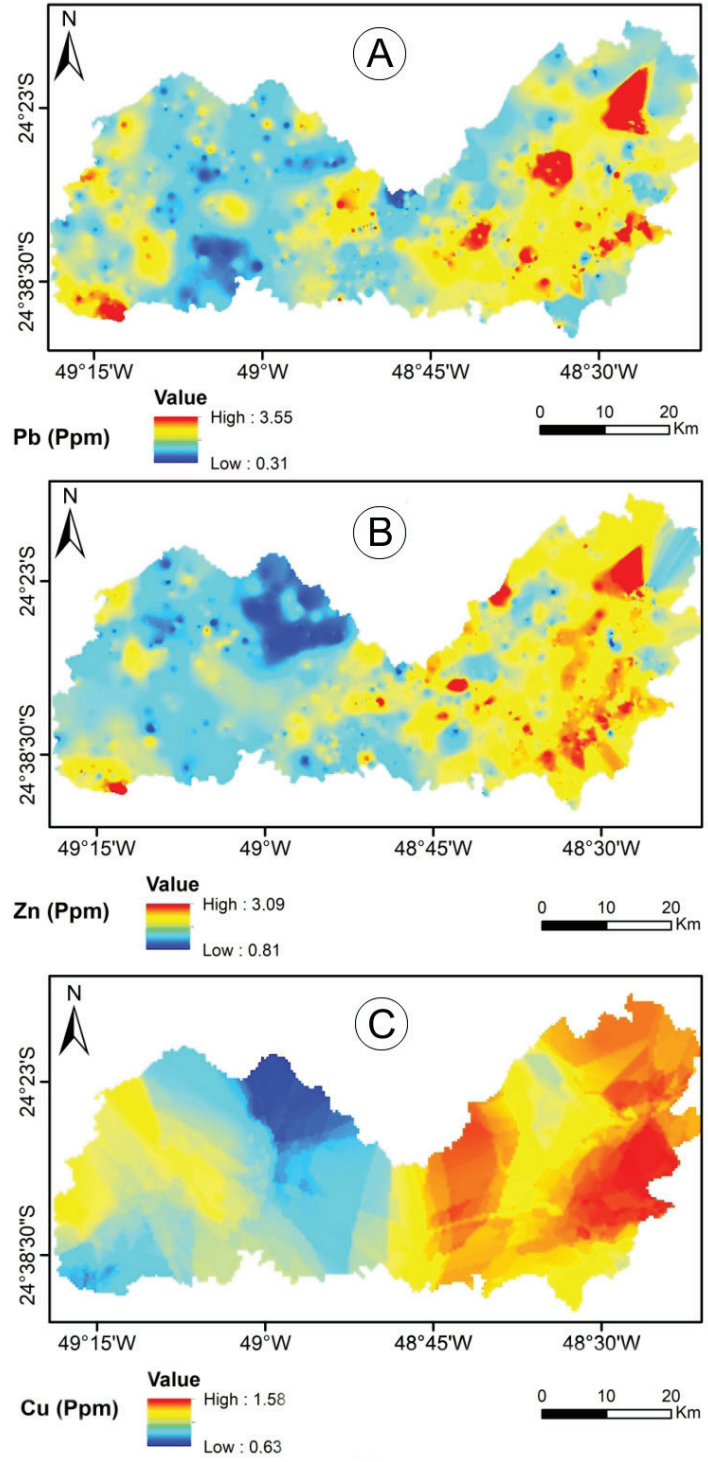

FIGURE 9 - Geochemical maps for each element: (A) lead concentration map; (B) zinc concentration map; (C) copper concentration map (geochemical data extracted from CPRM 2018).

\subsection{Favorability map}

The favorability map of veins-type lead deposits (Panelas model) was obtained by summing the different thematic maps through the algebraic equation given by equation 3 :

$\mathrm{F}=\mathrm{Sx}+\mathrm{Ty}+\mathrm{Lz}+\mathrm{Gt}$

In which:

$\mathrm{F}=$ favorability;

$\mathrm{S}=$ structure;

$\mathrm{T}=$ stratigraphy;

$\mathrm{L}=$ lithology;

$\mathrm{G}=$ geochemistry;

$\mathrm{x}, \mathrm{y}, \mathrm{z}$ and $\mathrm{t}=$ the respective weights.

\section{RESULTS}

The weights resulting from the judgment process for the alternatives and the factors are shown in table 5. They are used through the algebraic equations above for the construction of the thematic and final map (Figure 10).

\subsection{Structural map}

The structural map (Figure 10B) presents a large concentration of structures in the central and eastern region of the study area and a lower concentration in the western portion. These structures are dominated by NE-SW shear zones, which are very important for prospecting of veinstype lead deposit, since they are the main structure with ore veins (FIGUEIREDO 2000).

\subsection{Stratigraphic map}

The stratigraphic map (Figure 10C) presents the main stratigraphic units favorable to veins-type lead deposits. They are represented by the Mina de 
TABLE 5 - Factors and the alternatives with their respective weights.

\begin{tabular}{cccc}
\hline Factor & Weight & Alternative & Weight \\
\hline \multirow{3}{*}{ Structure } & \multirow{2}{*}{0.56} & Shear zone $(\alpha)$ & 0.63 \\
& & Fault $(\beta)$ & 0.26 \\
& \multirow{3}{*}{0.26} & Fold axe $(\lambda)$ & 0.11 \\
\hline \multirow{3}{*}{ Stratigraphy } & & Minas de Furnas Form & 0.30 \\
& & Bairro da Serra Form & 0.30 \\
& \multirow{2}{*}{0.12} & Água Clara Form & 0.30 \\
Lithology & Itaiacoca Form & 0.10 \\
& \multirow{3}{*}{0.06} & Dolomite & 0.63 \\
Geochemistry & Limestone & 0.26 \\
& & Metasedimentary rocks & 0.11 \\
\hline & & Lead $(\alpha)$ & 0.63 \\
& & Zinc $(\beta)$ & 0.26 \\
& & Copper $(\lambda)$ & 0.11 \\
\hline
\end{tabular}
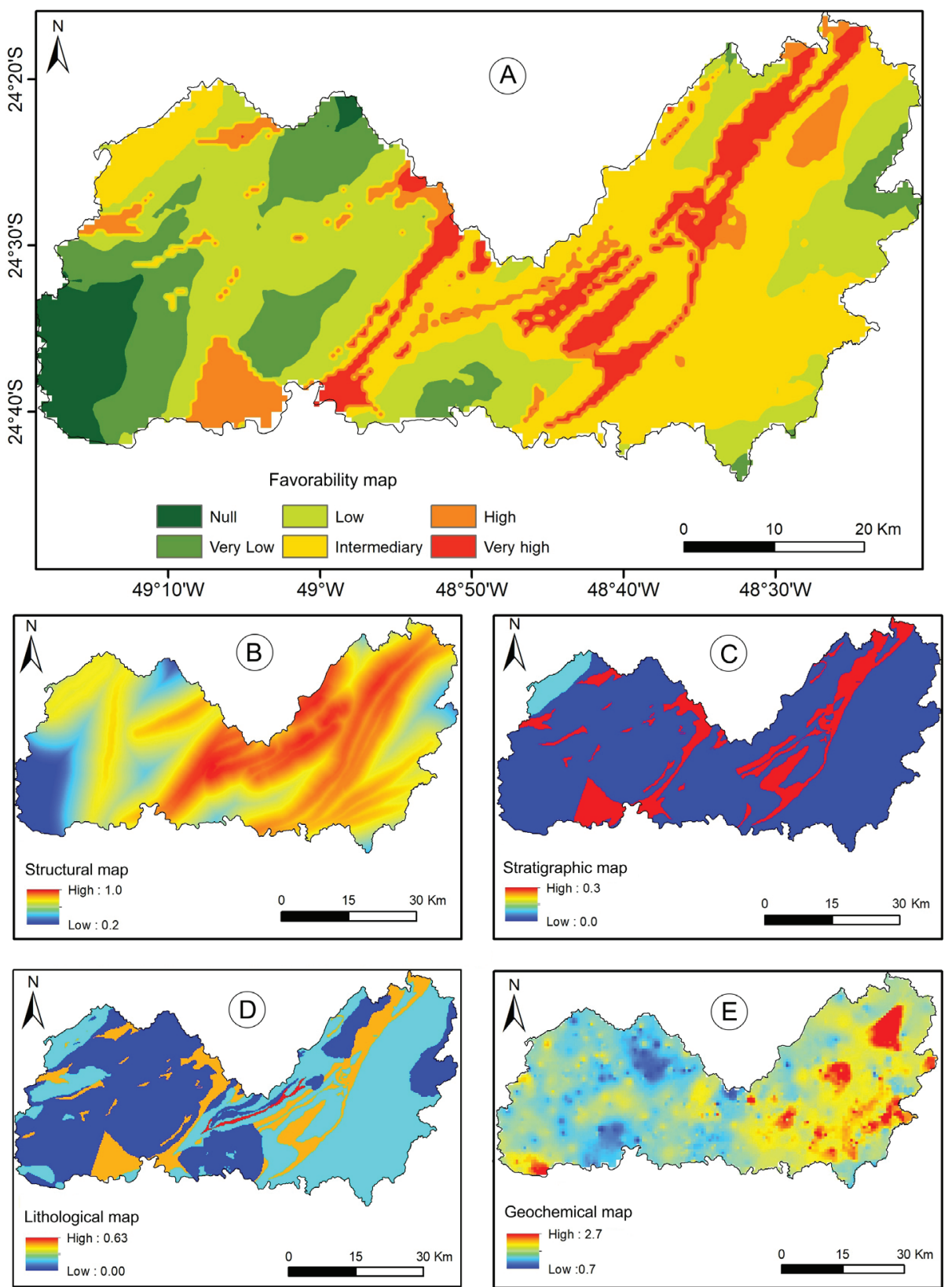

FIGURE 10 - (A) Favorability map obtained from sum of (B) structural, (C) stratigraphic, (D) lithological and (E) geochemical maps. 
Furnas, Bairro da Serra, Água Clara and Itaiacoca formations. The most favorable ones (Mina de Furnas and Bairro da Serra in the east, Água Clara in the west) are both presented in red color, and the Itaiacoca Formation, classified as the least important, is presented in light blue color in the northwest region of the study area.

\subsection{Lithological map}

The lithological map (Figure 10D) presents the different lithotypes favorable to the lead mineralization. They are represented by dolomitic rocks in red color (greater weight), limestone in yellow color (intermediate weight), metasedimentary rocks in light blue color (low weight) and igneous rocks in dark blue (null weight).

\subsection{Geochemical map}

The geochemical map (Figure 10E) presents the spatial distribution of concentration of all the elements.

\subsection{Favorability map}

The favorability map (Figure 10A) shows the spatial distribution of the areas according to their degree of favorability to find veins-type lead deposits. The west portion represents the part of the area that presents the lowest favorability, while the east and the central portions present the highest favorability or the best theoretical conditions for mineral prospecting. These areas (in red color) match the main structure concentration, Mina de Furnas, Bairro da Serra and Água Clara formations and the zones of greatest geochemical anomalies.

The statistics of this map are shown in the figure 11, whose values of minimum and maximum are 0.1789 and 0.6882 , respectively. The

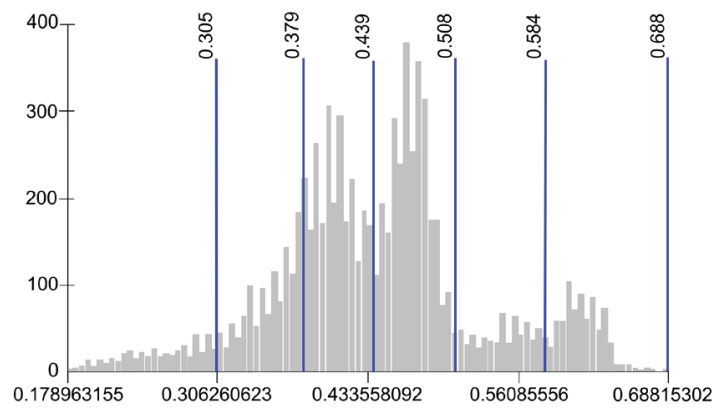

FIGURE 11 - Histogram of the favorability map showing the breaks and the peaks that were used to classify the final map. classification of the map was made by separating these values using the "natural breaks method", in which the software automatically identifies and separates the data in classes according to breaks separating the peaks. The number of classes determined for this map was six, being:

- null $(0.1790-0.3050)$;

- very low $(0.3051-0.3790)$;

- low (0.3791 - 0.439);

- intermediary $(0.4391-0.5080)$;

- high $(0.5081-0.5840)$;

- very high $(0.5841-0.6880)$.

In the histogram (Figure 11), three peaks more prominent represent the low, intermediary and very high favorability classes.

\section{DISCUSSION}

Besides the high coherence between the final map and the intermediate maps, this result conforms to the geological data of the rock outcrops of the area, corroborating previous studies in the region (e.g., ARAÚJO \& MACEDO 2004). This study highlights Mina de Furnas, Bairro da Serra and Água Clara formations as the lithostratigraphic units most favorable to polymetallic mineralization. According to SILVA et al. (2016), mineral occurrences of $\mathrm{Pb}$ are concentrated in the eastern and central regions of the study area, which corresponds to the Minas de Furnas and Bairro da Serra formations. In addition, mineral occurrence data provided by CPRM through the GeoSGB website and mineral resource map (scale: $1: 250,000)$ presented by CALTABELLOTTA et al. (2017) show many disabled lead ore mines such as Mina Jardim and Mina Santana Nova in this same zone, specially in Mina de Furnas and Bairro da Serra formations (Figure 12).

The high favorability of the Mina de Furnas and the Bairro da Serra formations to host veinstype lead deposits is due to the geological conditions represented by the presence of carbonate rocks (Figure 13) and structural features (Figure 10B) that constitute respectively geochemical traps and good percolation path for the hydrothermal fluids.

\subsection{Comparison with geophysical data}

The geophysicalfactorisrelevantin theprocess of mineral exploration, since certain geophysical techniques, such as gamma spectrometry, allow to delimit the hydrothermal alteration zones associated to mineral deposits (IRVINE \& SMITH 1990, SOARES et al. 2004). Gamma spectrometry 


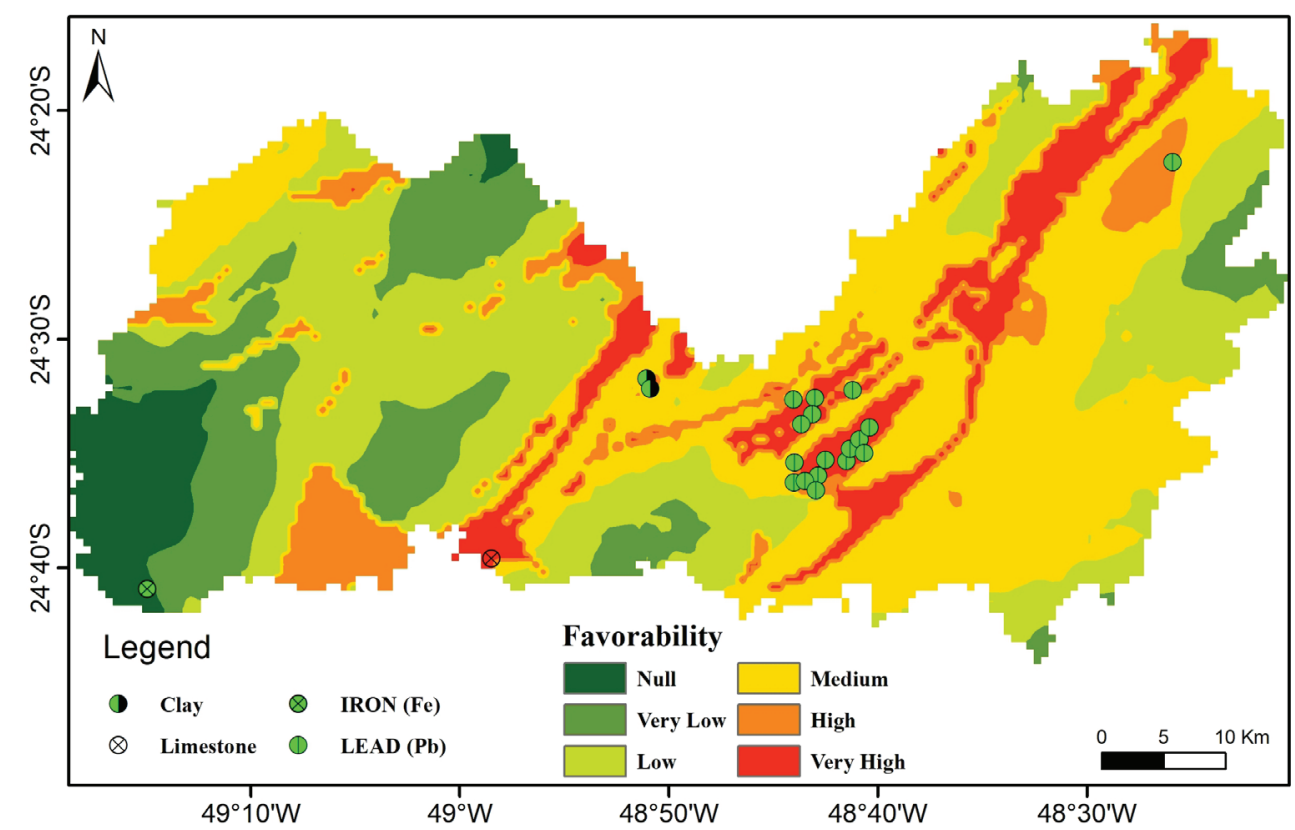

FIGURE 12 - Mineral occurrences in the study area (mine data extracted from CPRM 2018 and CALTABELLOTTA et al. 2017) plotted on the map of favorability.

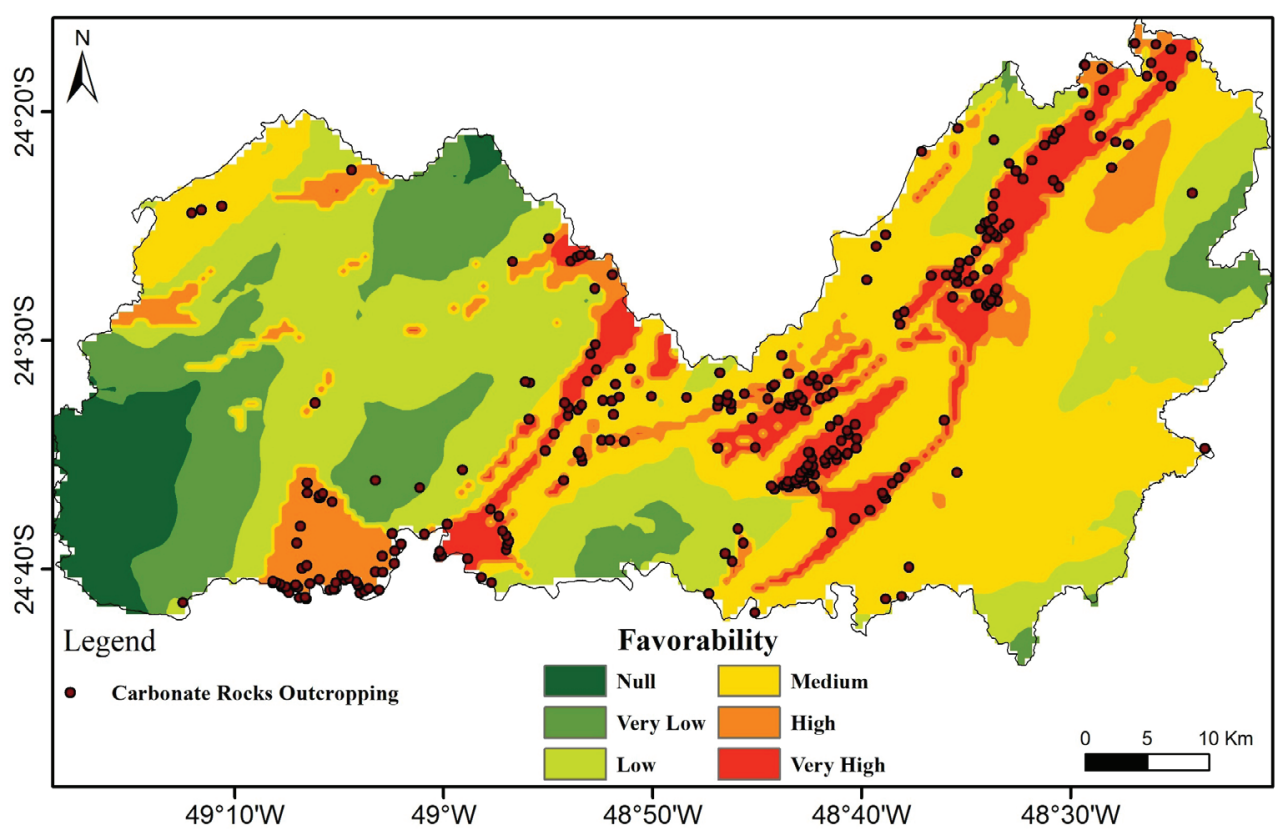

FIGURE 13 - Figure showing the main carbonate rocks outcropping in the study area (carbonate rocks outcropping extracted from CPRM (2018) plotted on the map of favorability.

provides information about potassium, uranium and thorium concentrations that may indicate hydrothermal alteration zones and, thus, the presence of potential mineral deposits. According to and IRVINE \& SMITH (1990) and PIRES (1995), ${ }^{40} \mathrm{~K}$ represents an important constituent of the hydrothermal solutions. RIBEIRO et al. (2013) showed that, in an environment of hydrothermal alteration, potassium and uranium move together leaving the thorium immobile. Nevertheless, in the absence of hydrothermal alteration, uranium and thorium tend to remain together. Potassium is an important chemical constituent of granitic rocks. WASSERBURG et al. (1964) showed that granites 


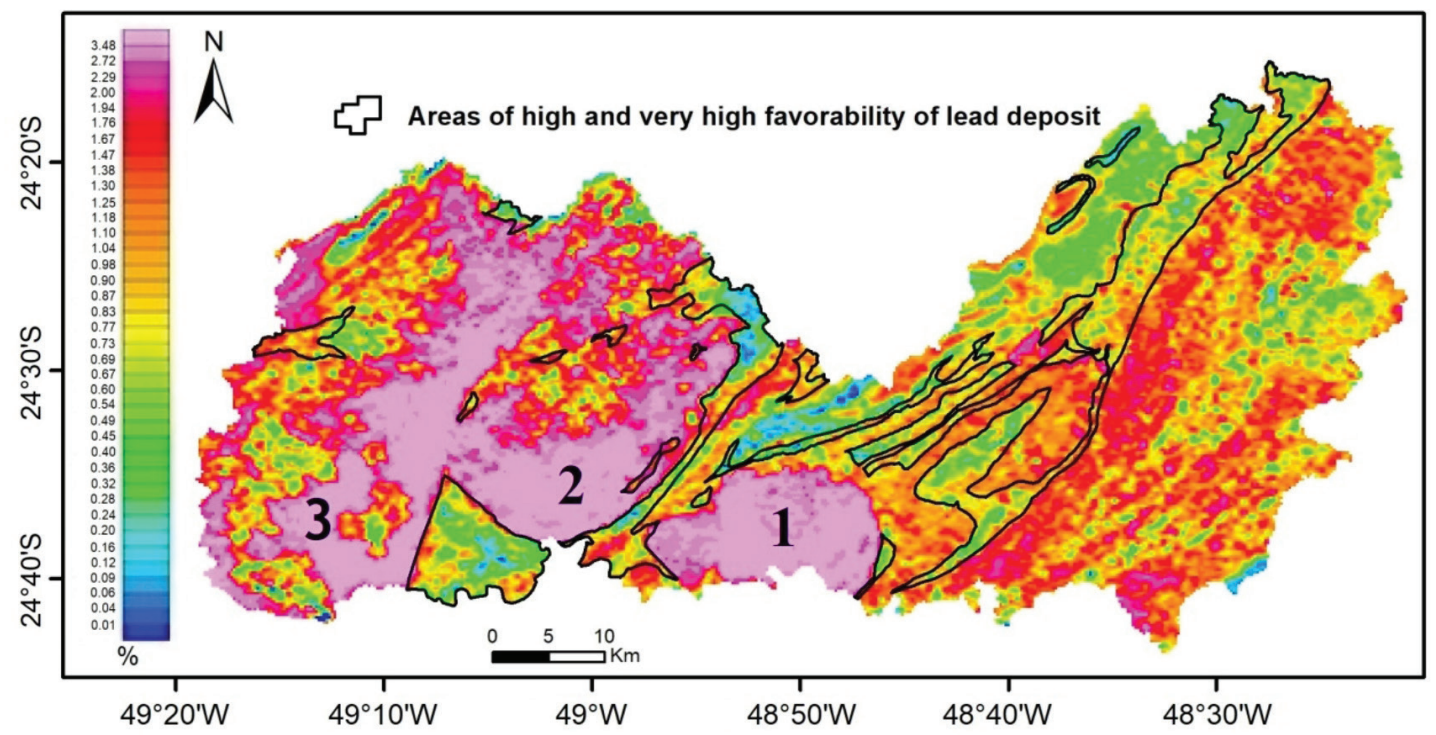

FIGURE 14 - Spatial distribution of potassium concentration. The highest concentration is associated with granitic bodies represented by (1) Itaoca granite, (2) Barra do Chapéu granite, and (3) Arrieiros granite. The highlighted areas are highly favorable to lead mineral deposit (geophysical map extracted from CPRM 2018).

have high concentration of this element in relation to other rocks. The figure 14 clearly shows that the highest concentration of potassium is associated with granite bodies, mainly the Itaiacoca Granite (1), the Barra do Chapéu Granite (2) and the Arrieiros Granite (3). In addition, a negative correlation between the areas of high favorability to mineral deposits and potassium anomalous is observed. The potassium concentration of the areas with high and very favorability do not exceed $1.76 \%$. Indeed, those areas are relatively poor in potassium and have no relationship with the other radioactive elements ( $U$ and $T h$ ). In such case, it is possible to conclude a negative association of the potassium concentration with the polymetallic mineral deposits $(\mathrm{Pb}, \mathrm{Cu}, \mathrm{Zn})$ in Ribeira Valley.

\section{CONCLUSION}

GIS and geoprocessing become, respectively, necessary tool and technique for mineral prospecting. Based on the data collected in the field and information extracted from previously performed works, they can allow the modeling of spatial distribution of geologically favorable areas to mineral deposits. Through this modeling, the potential areas can be identified and chosen for execution of more advanced stages of mineral survey.

In the present work, mapping of areas potentially mineralized with lead ore veins was executed by using GIS and geoprocessing together with AHP. Based on literature data (structural and lithological control in the mineral deposits), a spatial projection (or modelling) was made in order to identify other areas with probability of mineralization. The spatial projection consists of mapping areas with the same geological characteristics as a given area scientifically studied. These characteristics are represented by lithology, stratigraphy and geological structure.

For this work, AHP played a very important role, allowing the non-random weighting of the different factors involved. It is a robust method used in conjunction with GIS in geoenvironmental analysis, but its application is universal and can be used in any scientific field. The result obtained in this work proves its applicability for mineral prospecting and allows discriminating zones with high probability of hydrotermal vein-type $\mathrm{Pb}$ deposits, which can be used as a target of more advanced mineral prospecting.

\section{ACKNOWLEDGEMENTS}

Joël Viltus highly acknowledges Silmara C.P. F. Nunhez for revising the text, and the Coordination for the Improvement of Higher Education Personnel (Coordenação de Aperfeiçoamento de Pessoal de Nível Superior-CAPES) for its financial support to his academic activities in Brazil. The authors also thanks the reviewers for the valuable suggestions. 


\section{REFERENCES}

ARAÚJO, C.C. 1999. Aplicação de geoprocessamento na análise de favorabilidade para mineralizações de chumbo, zinco e cobre nas folhas Cerro Azul e Apiaí, Vale do Ribeira (SP e PR). Instituto de Geociências, Universidade de São Paulo, São Paulo, Master Degree Dissertation, $164 \mathrm{p}$.

ARAÚJO, C.C.; MACEDO, A.B. 2004. Aplicação de geoprocessamento na análise de favorabilidade para mineralizações de chumbo, zinco e cobre nas folhas Cerro Azul e Apiaí, Vale do Ribeira (SP e PR). Revista Brasileira de Geociências, 34(3): 317-328.

BARBOUR, A.P.; BRITO NEVES, B.B.; MEDEIROS R.A. 1990. Algumas implicações tectônicas na gênese das mineralizações sulfetados do tipo Panelas do Vale do Ribeira, SP, PR. Revista Brasileira de Geociências, 20(1-4): 46-54.

BASEI, M.A.S.; SIGA JR., O.; MACHIAVELLI, A.; MANCINI, F. 1992. Evolução tectônica dos terrenos entre os cinturões Ribeira e Dom Feliciano (PR-SC). Revista Brasileira de Geociências, 22(2): 216-221.

BURROUGH, P.A.; MCDONNELL, R.A. 1998. Creating continuous surfaces from point data. In: P.A. Burrough, M.F. Goodchild, R.A. McDonnell, P. Switzer, M. Worboys (eds.). Principles of Geographic Information Systems. Oxford, Oxford University Press, p. 132-161.

CALTABELLOTTA, F.O.; PAVAN, M.; RODRIGUES DA SILVA, A.D.; ALMEIDA, V.V.; BRUMATTI, M.; LOPES, A.P.; LIMA, R.A.P.; EVERINO, R.R.; ANDRADE, J.J.C.; PALMEIRA, L.C.M.; MAPA, F.B.; MARQUES, I.P.; TURRA, B.B.; COSTA, V.S.; CAMPOS, F.F.; FERRARI, V.C.; MENDES, D. 2017. Mapa de Recursos Minerais do ARIM Vale do Ribeira (SP e PR). Escala 1:750.000. Departamento de Recursos Minerais (DEREM), CPRM, São Paulo.

CAMPANHA, G.A.C. 1991. Tectônica proterozoica no alto e médio Vale do Ribeira, estados de São Paulo e Paraná. Instituto de Geociências, Universidade de São Paulo, São Paulo, Thesis, $307 \mathrm{p}$.
CAMPANHA, G.A.C.; SADOWSKI, G.R. 1999. Tectonics of the southern portion of the Ribeira belt (Apiaí domain). Precambrian Research, 98(1-2): 31-51. http://dx.doi. org/10.1016/S0301-9268(99)00027-3

CHIODI FILHO, C.; ALEGRI, V.; BATOLL, F.; FERREIRA, J.C.G. 1982. Geologia e mineralizações da região que abrange as minas do Rocha. Paqueiro Barrinha, Vale do Ribeira, PR e SP. In: SBG, CONGRESSO BRASILEIRO DE GEOLOGIA, 32, 1982, Anais, p. 1037-1048.

CHMYZ, L.; RIBEIRO, J.C.; ZARAMELLA, D.R. 2011. Considerações quanto ao potencial mineral da região do Arroio do Tanque, Vale do Ribeira (Adrianópolis, PR). In: ENCONTRO INTERNACIONAL DE PRODUÇÃO CIENTÍFICA, 7, Maringá, 2011, Anais, 5 p.

CPRM - COMPANHIA DE PESQUISA DE RECURSOS MINERAIS. 2006. Projeto Alto Ribeira. Available in http://www.cprm.gov. br/publique/Geologia/Geologia-Basica/ Projeto-Alto-Ribeira-350.html. Accessed on Sept. 15, 2018.

CPRM - COMPANHIA DE PESQUISA DE RECURSOS MINERAIS. 2018. Geochemical data. CPRM database. Available at: http:// geowebapp.cprm.gov.br/ViewerWEB/index_geoquimica.html. Accessed on Aug. 10, 2018 .

DAITX, D.C. 1996. Origem e evolução dos depósitos sulfetados tipo Perau ( $\mathrm{Pb}-\mathrm{Zn}-\mathrm{Ag}$ ), com base nas jazidas de Canoas e Perau (Vale do Ribeira, PR). Instituto de Geociências e Ciências Exatas, Universidade Estadual Paulista "Júlio de Mesquita Filho", Rio Claro, Thesis, $453 \mathrm{p}$.

DEHLER, N.M.; MACHADO, R.; VASCONCELOS, C.S. 2000. Tectônica extensional oblíqua no sul do estado de São Paulo. Revista Brasileira de Geociências, 30(4): 699-706.

EMSBO, P.; SEAL, R.R.; BREIT, G.N.; DIEHL, S.F.; SHAH, A.K. 2016. Sedimentary Exhalative (Sedex) Zinc-Lead-Silver Deposit Model. In: U.S. Geological Survey \& U.S. Department of the Interior. Mineral Deposit Models for Resource Assessment. United 
States, U.S. Geological Survey \& U.S. Department of the Interior, $57 \mathrm{p}$. http://dx.doi. org/10.3133/sir20105070N

FALEIROS, F.M.; MORAIS, S.M.; COSTA, V.S. 2012. Geologia e recursos minerais da folha apiaí SG.22-X-B-V. Escala 1:100.000. Brazil, Geological Survey of Brazil (CPRM). Available in http://rigeo.cprm.gov.br/xmlui/ handle/doc/11366?show=full. Acessed on Dec. 29, 2018.

FIGUEIREDO, B.R. 1992. Modelos de depósitos minerais. Boletim do Instituto de Geociências da Universidade de São Paulo, Série Científica, 23: 75-96. http://dx.doi.org/10.11606/ issn.2316-8986.v23i0p75-95

FIGUEIREDO, B.R. 2000. Minérios e ambiente. Editora da Unicamp, Campinas, 400 p.

FLEISCHER, R. 1976. A pesquisa de chumbo no Brasil. In: SBG, CONGRESSO BRASILEIRO DE GEOLOGIA, 29, Ouro Preto, Anais, 1, p. 19-32.

FRIZZO, S.J.; LICHT, O.A.B. 2007. Estatísticas Uni e Bivariadas Aplicadas à Prospecção Geoquímica. In: O.A.B. Licht, C.S.B. Mello, C.R. Silva (eds.). Prospecção Geoquímica de Depósitos Minerais Metálicos, Não Metálicos, Óleo e Gás. Brasil, Sociedade Brasileira de Geoquímica (SBGq)/Serviço Geológico do Brasil (CPRM), p. 595-618.

HASUI, Y.; CARNEIRO, C.D.R.; COIMBRA, A.M. 1975. The Ribeira Folded Belt. Revista Brasileira de Geociências, 5(4): 257-262.

HASUI, Y.; SADOWSKI, G.R. 1976. Evolução geológica do Pré-Cambriano na região sudeste do Estado de São Paulo. Boletim do Instituto de Geociências da Universidade de São Paulo, Série Científica, 6: 180-200.

IRVINE, R.J.; SMITH, M.J. 1990. Geophysical exploration for epithermal gold deposits. Journal of Geochemical Exploration, 36(13): 375-412. https://doi.org/10.1016/03756742(90)90061-E

JAKOB, A.A.E. 2003. Análise Sócio-Demográfica da Constituição do Espaço Urbano da Região Metropolitana da Baixada Santista no período 1960-2000. Instituto de Filosofia e Ci- ências Humanas, Universidade Estadual de Campinas, Campinas, Thesis, $220 \mathrm{p}$.

KOCH, G.S.; LINK, R.F. 1970. Statistical analysis of geological data. Dover Publications Inc., New York, 2 v.

LEVINSON, A. 1980. Introduction to Exploration Geochemistry. Illinois, Applied Publishing Ltd, $2^{\text {nd }}$ ed., 924 p.

LOPES, A.P.; RIBEIRO, L.M.A.L.; SALVADOR, E.D.; PAVAN, M.; SILVA, A.D.R. 2017. Áreas de relevante interesse mineral - Vale do Ribeira: Mineralizações polimetálicas $(\mathrm{Pb}$, $\mathrm{Ag}, \mathrm{Zn}, \mathrm{Cu}$ e $\mathrm{Au}$ - "tipo Panelas") em zonas de cisalhamento rúptil, Cinturão Ribeira meridional, SP-PR. Brasil, Serviço Geológico do Brasil (CPRM), 120 p.

MACEDO, A.B. 1987. Prospecção litogeoquímica na mina do Perau, Paraná, São Paulo. Instituto de Geociências, Universidade de São Paulo, São Paulo, Thesis, 162 p.

MARINI, O.J.; TREIN; E.; FUCK, R.A. 1967. O Grupo Açungui no estado do Paraná. In: J.J. Bigarella, R. Salamuni, V.M. Pinto (eds.). Geologia do Pré-Devoniano e Intrusivas Subseqüentes da porção oriental do Estado do Paraná. Curitiba, Universidade Federal do Paraná, p. 43-100.

MARINS, C.S.; SOUZA, D.O.; BARROS, M.S. 2009. O uso do método de análise hierárquica (AHP) na tomada de decisões gerenciais - um estudo de caso. In: SIMPÓSIO BRASILEIRO DE PESQUISA OPERACIONAL, 41, Pesquisa Operacional na Gestão do Conhecimento, p. 1778-1788.

MORAIS, S.M. 2017. Mapa de Recursos Minerais do ARIM Vale do Ribeira (SP e PR). Carta Geológica, Escala 1:250.000. Serviço Geológico do Brasil (CPRM), São Paulo.

MORAIS, S.M.; FALEIROS, F.M.; COSTA, S.V.; GOMES, S.D.; CHIEREGATI, L.A. 2012. Mapa geológico folha Apiaí - Escala 1:100.000. Serviço Geológico do Brasil (CPRM), São Paulo.

ODAN, Y.; FLEISCHER, R.; ESPOURTEILLE, F. 1978. Geologia da mina de chumbo de Panelas Adrianópolis - PR. In: SBG, CONGRES- 
SO BRASILEIRO DE GEOLOGIA, 30, Recife, Anais, 4: 1545-1552.

PIEKARZ, G.F. 1981. Reconhecimento de unidades correlacionáveis à sequência mineralizada do Perau, Estado do Paraná. In: SBG, SIMPÓSIO REGIONAL DE GEOLOGIA, 3, Curitiba, Atas, 1: 148-154.

PIRAJNO, F. 2009. Hydrothermal process and mineral systems. Springer Science and Business Media B.V., Australia, 125 p.

PIRES, A.C.B. 1995. Identificação geofisica das áreas de alteração hidrotermal, Crixás-Guarinos, Goiás. Revista Brasileira de Geociencias, 25(1): 61-68.

RIBEIRO, V.B.; MANTOVANI, M.S.M.; LOURO, V.H.A. 2013. Aerogamaespectrometria e suas aplicações no mapeamento geológico. Terrae Didática, 10(1): 29-51. https://doi. org/10.20396/td.v10i1.8637386

ROSSI, M; DEUTSCH, C.V. 2014. Mineral resource estimation. Springer, Dordrecht, $332 \mathrm{p}$.

SAATY, T.L. 1977. A scaling method for priorities in Hierarchical structures. Journal of Mathematical Psychology, 15(3): 234-281. https://doi.org/10.1016/0022-2496(77)90033-5

SAATY, T.L. 2002. Decision Making with the Analytic Hierarchy Process. Scientia Iranica, 9(3): 215-229.

SILVA, A.D.R.; MARQUES, I.P.; BRUMATTI, M. 2016. Áreas de relevante interesse mineral Vale do Ribeira - ARIM: Mapa de recursos minerais da região do Grupo Lajeado - Minas de Furnas e Lajeado - Escala 1:25.000. Brasil, Serviço Geológico do Brasil (CPRM).

SILVA, A.T.S.F.; FRANCISCONI, O.; GODOY, A.M.; BATOLLA JUNIOR, F. 1981. Proje- to integração e detalhe geológico no Vale do Ribeira. Brasil, Serviço Geológico do Brasil (CPRM). Available in http://rigeo.cprm.gov. $\mathrm{br} / \mathrm{xmlui} /$ handle/doc/6904. Accessed on Nov. 20, 2018.

SILVA, B.C.E.; TEIXEIRA, J.A. 2012. Chumbo. In: Departamento Nacional de Produção Mineral (DNPM) (ed.). Sumário Mineral. Brasília, DNPM/Ministério de Minas e Energia, p. $49-51$.

SILVA, R.B.; MAEYAMA, O.; PEROSA, P.T.; ALMEIDA, E.B.; SARAGIOTTO, J.A.R. 1982. Considerações sobre as mineralizações de chumbo, zinco e prata do Grupo Açungui no Estado de São Paulo. In: SBG, CONGRESSO BRASILEIRO DE GEOLOGIA, 32, Salvador, Anais, 3: 972-986.

SOARES, M.S.; KOPPE, J.C.; COSTA, J.F.C.; ROLIM, S.B. 2004. Interpretação das anomalias de potassio hidrotermal e parametro $\mathrm{F}$ da região do Complexo Bossoroca, São Sepé, RS. Revista da Escola de Minas, 57(1): 39-44. http://dx.doi.org/10.1590/S037044672004000100008

WASSERBURG, G.J.; MACDONALD, G.J.F.; HOYLE, F.; FOWLER, W.A. 1964. Relative Contributions of Uranium, Thorium, and Potassium to Heat Production in the Earth. Science, 143(3605): 465-467. http://dx.doi. org/10.1126/science.143.3605.465

WINGE, M. 2001. Glossário Geológico Ilustrado. Available in http://sigep.cprm.gov.br/glossario. Accessed on Dec. 10, 2018.

YAMAMOTO, J.K.; LANDIM, P.M.B. 2013. Geoestatística: Conceitos e Aplicações. Oficina de Textos, São Paulo, 215 p.

\section{Authors'address:}

Joël Viltus e Marcel de Souza Bonfim - Instituto de Geociências, Universidade Estadual de Campinas, Cidade Universitária Zeferino Vaz, Barão Geraldo, CEP: 13083-970, Campinas, SP, Brazil. E-mail: jmunicamp985@gmail.com.

Manuscript submitted on 12 september 2018, accepted on 30 december 2018. 